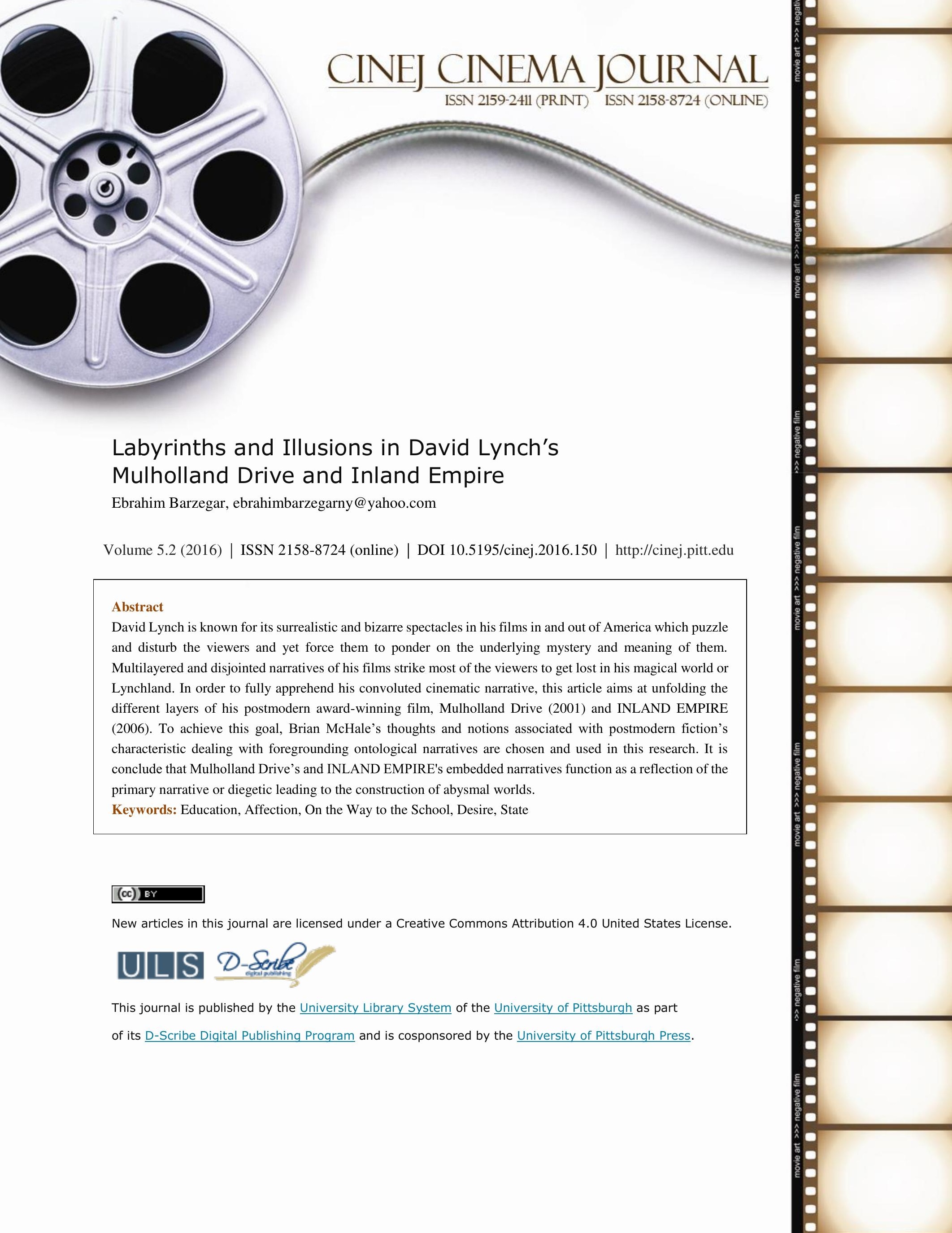




\section{Labyrinths and Illusions in David Lynch's Mulholland Drive and Inland Empire}

\section{Ebrahim Barzegar}

\section{Theoretical Background: Ontological Perspective}

Western philosophical tradition is divided into two major challenges. On the one hand, it questions what do we know and on the other hand, what exists which former issue is known as epistemology and the latter ontology. To followers of ontological philosophy, for solving the problem of what do we know one should first solve the problem of what exists; therefore, "they give precedence to existence over knowledge" (Jarvie, 2003, p.34).

Brian McHale in Postmodernist Fiction differentiates modernist and postmodernist fiction in relationships of two different "dominants". He argues that "postmodernist fiction differs from modernist fiction just as a poetics dominated by ontological issues differs from one dominated by epistemological issues". (McHale 2004, p. xii) From his standpoint, "the dominant of modernist fiction is epistemological" (ibid. p. 9). Therefore, modernist fiction is mostly concerned with epistemological questions such as "How can I interpret this world of which I am a part? [...] What is there to be known?; Who knows it?; How do they know it, and with what degree of certainty?" (ibid). The propellers of this philosophy strongly believed that one can possibly know the world we are living in and elucidate our perception toward it by means of rational assessment and logical reasoning. Taking for granted that all the unanswered questions could be replied based on knowledge-centred way of thinking, epistemology, thus, depends on the assumed presence of "grand narratives" which provides sound scaffolding for turning to. In postmodernism, McHale argues, these "various stories (Enlightenment, Marxist, Hegelian) about human emancipation and progress that once served to ground and legitimate knowledge, 
are no longer credible" (ibid. p. 5). Hence that is where the postmodern idea of ontology generated and welcomed.

Ontological questions in postmodernism function as generators of instability and uncertainty. Being, in postmodernism, is spread across multiple worlds that often exist simultaneously, thus blurring or emphasizing the ontological boundaries between such worlds and on top of that, the reality which is the central issue of postmodern fictions. To postmodern philosophers, reality is a formation; it is a construction-based entity. Since presentation of nonentity is out of the question, postmodern texts display tendency toward reflecting the idea of fabricated reality by means of postmodern techniques like mise-en-abyme and Trompe-l'oeil.

Mise-en-abyme literally means 'placed into abyss" and originally came from a heraldic term which points to an escutcheon bearing in its centre a miniature replica of itself. The term entered into literary text in 1893 by the French writer, Andre Gide and since then it was widely used to describe "self-reflexivity or self-consciousness in fiction" (Sim,2001, p. 318). In his journal from 1893, Gide remarked that:

In a work of art, I rather like to find thus transposed, at the level of the characters, the subject of the work itself. Nothing sheds more light on the work or displays the proportions of the whole work more accurately. [...] What would be more accurate, and what would explain better what I'd wanted to do in my Cahiers, in Narcisse and in La Tentative, would be a comparison with the device from heraldry that involves putting a second representation of the original shield 'en abyme' within it. (qtd. in Dallenbach, 1989, p. 7)

Generally speaking, mise-en-abyme is a story within a story; similar to babushka dolls it resembles the larger narratives. It is one of the most effective techniques in the postmodern text for foregrounding the ontological dimension of the structures. According to Brian McHale's book Postmodern Fiction, three criteria determine the mise-en-abyme construction: 
first, it is a nested or embedded representation, occupying a narrative level inferior to that of the primary, diegetic narrative world; secondly, this nested representation resembles something at the level of the primary, diegetic world; and thirdly, this "something" that it resembles must constitute some salient and continuous aspect of the primary world, salient and continuous enough that we are willing to say the nested representation reproduces or duplicates the primary representation as a whole. $(2004$, p.124)

John Barth' collection of short stories Lost in the Funhouse is a good example of this technique. In a story entitled Lost in the funhouse the narrator, Ambrose, is expressing the problem of making the story, "Lost in a Funhouse", in which the main character, Ambrose, is lost in the funhouse. Dream within a dream is the parallel construction of mise en abyme in film where a character awakes from a dream and later discovers that s/he is still dreaming. In eXistenZ (David Cronenberg, 1999), the two protagonists participate in the game narratives one after another without knowing which are real or unreal. Inception (Christopher Nolan, 2010) is another recent example of mise en abyme construction in film that the main character, Dom Cobb, constructs a three-stage dream in order to implant an idea into his target's mind.

Trompe l'oeil was a term coined in the Baroque period but was a phenomenon already evident in Greek and Roman times. It literally means 'fool the eye' and so the apparent aim of these paintings was to pose as three dimensional reality; to deny the physical properties of the painting itself. Painters adopting Trompe l'oeil techniques had a different approach to reality. Trompe-l'oeil pictures aim to achieve illusion with pictorial means.

In postmodern texts pictorial illusion is replaced by narrative one. Postmodern writers could be taken as illusionists who beckon the readers to the magical realm of words and texts. They intend to blend and misplace the narrative levels of their story so as to puzzle the readers, which in most cases are effective. Regarding the idea of illusory quality of postmodernist writings, Brian McHale asserts that: 
Postmodern texts nurture trompe l'oeil deliberately misleading the reader into regarding an embedded, secondary world as the primary, diegetic world. Typically, such a deliberate "mystification" is followed by "demystification" in which the true ontological status of the supposed "reality" is revealed and the entire ontological structure of the text consequently laid bare. (2004, p. 115)

It should be noted that the illusion is ephemeral; nevertheless it has the desired effect, unbalancing the reader's well-defined levels of mind. Having been introduced to this so-called real world, the readers found it hard to entirely discard this viewpoint.

\section{Labyrinths and Illusions in Mulholland Drive}

In Lynchland, Winkie's restaurant is the "locus of imagination" in construction of abysmal world in Mulholland Drive because it is the point where dreams and dreaming intermingle with each other (Roche, 2004, p.44). Winkie's name connotes the winking or blinking movement of eyes, so it suggests that what is happening here is just a dream (Thomas, 2008, p. 86). There are three levels of dream within a dream sequence in Mulholland Drive that all represented at Winkie's restaurant.

On the first level, an analysand (named Dan) and his analyst (named Herb) are shown having a conversation about a dream,

I had a dream about this place. It's the second one I've had. But they're both the same. They start out that I'm in here. It's not day or night. It's kind of halfknight, you know? But it looks just like this. And I'm scared like I can't tell you. $(0: 12: 11-0: 12: 55)$

The pre-shot and post-shot suggest that it is Rita's dream; therefore, as far as the narrative is concerned, Winkie's scene is at the hypodiegetic level. The setting and the position of the two characters mirror Betty and Rita's meeting in the following sequence. Thematically 
speaking, it should be noted that if Betty and Rita change to Dan and Herb, there is reason for that Thomas explains as "psychic distantiation". He adds that,

Here, by letting the dark-haired woman dream of Dan's dying to see the reality behind his dream, the dreaming Diane protects herself from facing the fact that she can get rid of her god-awful feeling of guilt for having in fact gotten rid of Camilla only through getting rid of herself, a good riddance that comprises a major facet of the 'fundamental fantasy 'of her dream. (2008, p. 153-154)

She is scared of her fate, death. The degree to which her fear is perceived mirrors the degree of Rita's psychological trauma. Since the scene is Rita's dream within Diane's dream, according to McHale, it "occupies an inferior narrative level" and could be construed as duplication (2004, p. 126).

Linda Hutcheon described the mise en abyme construction as a "simple reduplication, in which the mirroring fragment has a relation of similitude with the whole that contains it" (1980, p. 55). Betty's and Rita's conversation at Winkie's is a 'simple duplication' of the preceding and following scene in the film. After calling police for a car accident report on phone, Betty and Rita decide to have cups of coffee at Winkie's. They sit in the exact position described in previous scene. Seeing the tag name of the waitress, Diane, Rita said: "I remember something", and then suggested that "Diane Selwyn. Maybe that's my name". Rita's sudden discovery of her identity at this point at one level hints at the doppelganger figure, a visual duplication and one the second level represents "postmodern preoccupation with being and seeming" (Burningham, 2010, p. 37).Therefore, as far as ontology's concerned, Rita and Betty are in hypodiegetic level, a reflection of another world. The following scene in which they call Diane Selwyn's home increase the possibility of another world.

Betty: it's strange to be calling yourself.

Rita: Maybe it' not me. 
Rita: That's not my voice. But I know her. (0:55:41-0:56:01)

Through these remarks, Lynch gives us a clue that there exists another world despite character's unawareness. According to Dallenbach, the reader/viewer has a more privileged insight than the character into a mise en abyme's significance (1989, p. 86). Moreover, the haunting image of the dead corpse at Diane's apartment parallels the black-fungus-covered face behind the restaurant's wall. In the both cases, the characters meet their awaiting fate, death. Indeed, the corpse functions as an analepsis inviting the viewer to reassess the initial interpretation of Dan's premonition (Olson, 2008, p.531). As McGowan showed in his psychoanalytic analysis of the film, the first part of the Mulholland Drive entirely belong to Diane's fantasy, 'a gesture that' she assumed could "promises respite from her tortures of desire" but ultimately "came back to haunt" her (2007, p. 218). Betty's and Rita's figures who are successful actress and faithful lover respectively mirror the first diegesis characters, Camilla and Diane.

Finally in the real part of the film, the source of discussed hypodiegetic levels is shown to viewers and it is again at Winkie's. Being a loser in career and romantic life, Diane hires a hitman to kill Camilla. After handing the money over, Diane sees Dan over the counter and feels scared. Diane's underlying fear uttered earlier by Dan,

Of all people you're standing right over there. By that counter. You're in both dreams and you're scared. I get even more frightened when I see how afraid you are, and then I realize what it is. There is a man in back of this place. He's the one who's doing it. I can see him through the wall. I can see his face. I hope that I never see that face ever outside of the dream. That's it. (0:12:59$0: 14: 07)$.

All Diane wants is "to get rid of this god-awful feeling" that Dan said to his analysand, Herb. Structurally and thematically, Dan's appearance in the earlier scene reflects Diane's emotional trauma. In order to suppress her guilt, Diane acts like "Hindu myths in which people 
become so entangled in each other's dreams and dreams-within-dreams that readers cannot help but feel confused about the basic existential question of what is real" (Bulkeley, 2003, p.52).

Among other Lynch's films Wild at Heart, Lost Highway and INLAND EMPIRE also include hypodiegetic worlds which could be taken as reflection. Lula's life in Wild at Heart explicitly reflects Dorothy's journey in The Wizard of $\mathrm{Oz}$. Lula frequently quotes lines that directly refer to the hypodiegetic level of story. Take this line, "We broke down on that yellow brick road" (Lula said to Sailor at motel) as an example. She compares herself as Dorothy who should struggle to overcome troubles so as to get home. The yellow brick road, the Wicked and $\mathrm{Oz}$ at hypodiegetic level are duplicated by Lynch in diegetic level into continual yellow lines of road, Lula's possessive mother and golden state of California respectively. The Wizard of $O z$, narratively and thematically, functions as the intertextual reflection of "an inferior narrative level, a world within the world" diegesis (McHale, 2004, p. 125).

Lost Highway also includes an embedded world within the primary diegesis which could be taken as duplication. The embedded diegesis is the reproduction of primary diegesis for two reasons. Firstly, the former includes a female character named Alice who is inaccessible to Pete, much the same as Renee to Fred. Alice's sentence at the end of the movie in desert "You'll never have me" (1:56:07) verifies the unattainability of her. Secondly, the embedded story, as McHale said, shares the themes of betrayal, revenge and murder which "constitute salient and continuous aspect of the primary world" (McHale 2004, 124). Among cinematic examples Inception and eXistenZ (David Cronenberg, 1999) are two shining examples which display abysmal worlds in their diegesis. The former employed a mechanical dream within a dream model, and the latter used video game as its abysmal worlds. The uncertainty of the ending in both films enhances the possibility that he entered into another diegetic level and it may goes ad infinitum. 
Besides duplication of primary diegesis in Mulholland Drive, Lynch deploys trompe l'oeil technique to deceive his viewers. The French term means fool the eye, to deceive the viewers into believing something which is an illusion. In Mulholland Drive case, action and representation are given the illusive forms so as to mislead the viewers' attention.

One way of creating an illusion is acting. In the first part of the film, in a jump cut, camera shows Betty, casually dressed in a red bath towel, uttering words in resentment and anger to someone who appears to be Rita. "You are still here?" Betty said. And Rita, in a close-up shot replied back "I came back. I came that's what you wanted". Then the camera jumps to Betty shot and she said "nobody wants you here". These lines along with the camera shots give the impression that caring Betty is gone and she aims to get rid of traumatized Rita. But as viewers are getting ready to perceive the new situation, camera zooms out and reveals the audition script in Rita's hands. At this point, viewers understand that they were fooled by cinematic sleight of hand to take, in McHale's words, "secondary world as the primary world" for what Betty and Rita were saying was not real. It belongs to the film Betty is supposed to play a part in it (2004, p. 115). The opposite case has the same effect in McHale's viewpoint. The scene is represented in a way that the diegetic level pushes back into hypodiegetic level. This is what happens in audition scene. In the audition room in a close-up shot again, Woody and Betty's performance are so impressive and strong that no one for a single moment doubts the theatricality of the scene. Despite the director (Bob)'s suggestion not to "play it for real", the two actors act so well, intense voice and real tear of Betty are reinforcing, that it is real. However, it does not last for long, thanks for camera's zoom out. The film within a film level promotes into a higher level of film. In both cases, rehearsal and audition shots, Lynch deliberately attempts to deceive viewer so as to achieve his aim, destabilization of film status. 
Mulholland Drive includes a short narration in Club Silencio, bathed in two mysterious colors blue and red, which is considered as the paragon of Lynch's representation.

In there the Magician kept repeating in three different languages Spanish, French and English the following phrases:

No hay banda!/ There is no band / Il n'y a pas d'orchestre/ This is all in a tape Recording / No hay banda—/ And yet—we hear a band (1:45:10-1:45:31).

It's all a trick. The magician is the master of deception and trickery. Signifiers slide along the texture of celluloid so that when one follows a sign expecting to find a stable referent, one finds something missing (Coffeen, 2003, p. 2). Although he makes full disclosure of the magic, Betty and Rita, also the viewers still believe him. The magician of the Lynchland in total honesty shows the artificiality of the performance he is handling. "In a series of game", the magician "invites a remarkably self-directed form of enjoyment, permitting viewers to re-deceive themselves in the context of a revealed deception" (Manon, 2006, p. 61).

The Magician verbalized "a Muted Trumpet" (1:45:10) and an old man in white suit came to the view from the red curtain and started to play the trumpet. In a next moment, he stopped playing but the music could be heard. Standing in the corner, with a mischievously tone the magician declared that "It is all recoded" (1:46:32). The magician's performance and statement, "There is no band", in McHale's words, is the shining example of "mystification" which immediately is followed by "Yet we here the band", "demystification," in which ontological status of the supposed 'reality' is revealed and the entire ontological structure of the text consequently laid bare" $(2004,116)$. 
The scene has close affinity with the Belgian surrealist Rene Magritte' famous painting La Trahison des Images ${ }^{1}$ which the written sentence and the image are in striking contrast with each other; therefore, questions the concept of representation. Regarding the concept of illusion, Manon argues that "The fact that one may look at a painting for a period of time can limit the effectiveness of a trompe l'oeil painting, for it is not moving through time" $(2006,70)$ but Lynch's film does and that why his work is more effective and believable.

In Lynchland "Owls are not what they seem" (Twin Peaks), so is Rebekah Del Rio's performance. Introduced by the emcee as "The Crying Lady", she began to sing a Spanish version of Roy Orbison's “In Dreams” with a fake drop of tear on her face.

In dreams I walk with you.

In dreams I talk to you.

In dreams you're mine, all of the time...

It's too bad that all these things can only happen in my dreams

Only in dreams, in beautiful dream. (Devlin \& Biderman, 2011, p. 43)

For a short moment, Betty and Rita assume that what they are seeing is real, but all of the sudden she drops on the floor motionless while music is playing on. Betty, Rita and the film's viewers despite the magician's factual truth were fooled by their eyes again. In other words, Lynch's Grand Illusion ${ }^{2}$ constantly and ingeniously locates film's narrative in "in-between" world, a kind of No-Man Land ${ }^{3}$. The Red Room/Black Lodge of Twin Peaks and the cabin in the desert in Lost Highway are other examples of this note in Lynchland.

That Betty and Rita are crying and their tears are real highlights the possibility of the reality of the performance; however once more it turns out to be illusory. It is the most revealing

\footnotetext{
${ }^{1}$ Treachery of Images (1928) but commonly and mistakenly known as C'est ne pas pipe

2 Jean Renoir's film title (1937)

${ }^{3}$ Peter Werner's film title (1987)
} 
scene of the film for two reasons: one, what Rita and Betty are watching is an illusion, so is the entire film. In her analysis Schaffner argued that Lynch "shows us openly how and why both cinema and fantasy work by exposing their underlying structures and assumptions, and yet, crucially, we are still enchanted by his cinematic illusionism, in spite of seeing through its mechanics" (2009, p. 274). Two, it is the threshold, in Derridian sense, of the Diane's dream where the undesirable truth of her life comes to surface and puts an end to her fantasy. From Nochimson's viewpoint in Club Silencio, "Time and Space have come unglued, along with the identities of the three leading characters" (Sheen \& Davison, 2004, p.178).If her glorious arrival to her Aunt Ruth's mansion is taken as an "avenue into another world”, Rebekah Del Rio's performance is the swansong of her fantastic world (McMahon, 2011, p. 122). Lynch made his viewers to take the narration as an embedded one, hypodiegetic fantasy, and next he retuned back to the diegetic one. Femme Fatale's (Brian De Palma, 2002) narrative represented similar skill, for near the end of the movie viewers realize that what they were watching was again a dream.

As far as narratology is concerned, Mulholland Drive, as it discussed, contains several diegetic levels like a Chinese-box worlds that mirror the primary diegesis. These diegetic levels, in some cases promote or demote to another diegetic level, thus create an illusion and disillusion momentarily. The various levels of diegetic constantly refer and reflect one another in a way that creates a mise-en-abyme kind of structure. The primary narrative mirrors the embedded ones and vice versa.

\section{Empire of Labyrinths}

This section of the thesis analyses the various narrative levels of INLAND EMPIRE. Mise en abyme is a story within a story, similar to Chinese box or Russian babushka doll, which 
duplicates the larger narrative. Multiplying of nested narrative in fiction, as far as McHale is concerned, which does not encompass the continuous aspect of the main narrative is not considered as mise en abyme (2004, p.125). From McHale's viewpoint, mise en abyme and trompe l'oeil are the most frequent techniques employed in postmodern texts so as to foreground the ontological status of the text (2004, p.112-113). This part of the thesis has two sections. In the first part the mise en abyme structure and in the second part trompe l'oeil device in INLAND EMPIRE will be discussed.

Despite the unclear lines between the stories and words, the researcher attempts to discuss the mise en abyme structure of INLAND EMPIRE in three different diegetic levels or worlds so as to make slightly distinguishable to comprehend. Nikki Grace life in Los Angles, Sue Blue in On High Blue Tomorrows, the couple in Poland and Rabbits' staged show are the levels that will be examined in this part.

In INLAND EMPIRE, the embedded worlds which Nikki appears in seem to be the duplication and continuous aspect of her real life narrative. Regarding the concept of mise en abyme Anna Katharina Schaffner argues that:

Filming and acting form an endless series of mise en abyme; the boundaries between acting and non-acting, between the film within the film we are watching and films that are watched by characters within the film, are rendered fluid; the structure is labyrinthine, Chinese-box-like, but with boxes that are not clearly separable from each other. (2009, p.85)

INLAND EMPIRE revolves around Nikki Grace's real world as a married actress. Nikki is living in a luxurious LA mansion with her jealous husband, Piotrek, who gets a chance to play the leading role in a film. Although she states that she would "get on famously, in a professional way" (00:21:19) with Devon Berk, her male partner, in a TV show, Nikki gets involve 
in an extra-marital affair with Devon. That her husband finds the truth about the affair makes Nikki's mind and world to slip from its present ontological status into another one. So confused is Nikki that, her fictional and non-fictional worlds are barely distinguishable. While she was on stage she states that

Nikki: Something happened. I think my husband knows about you. About us. He'll kill you and me...he'll...damn, it sounds like dialogue from our script! (00:55:00).

The above sentences plainly display Nikki's fear and confusion in her real world, for she knows that, to borrow her bizarre neighbor's forewarning, "actions do have consequences" (00:17:30).

The first level of mise en abyme is constructed around the film-within-a-film. Nikki and Devon play their parts in On High Blue Tomorrows film as Sue Blue and Billy Side. In this hypodiegetic level, Billy and his wife, Doris, live in a mansion and Sue and Billy are having a love affair. The following statements assert the secret relationship between Sue and Billy.

Doris: Susan, what are you doing here?

Sue: What? I thought you were gone. Billy. Something is wrong...do you love me?

Doris: What?

Billy: Sue.

Sue: Billy, don't' you remember anything? How it was?... love you Billy.

Billy: Go away, Susan. (01:51:08-01:53:07)

The non-chronological order of the film's narrative and Nikki's lack of stable identity within each level make the following scene hard to determine if it belongs to real Nikki or Sue within the film,

Sue: It's a story that happened yesterday. But I know that it's tomorrow.

Billy: That doesn't make sense.

Sue: It was that scene that we did yesterday. When I'm getting groceries for you with your car and I was in that alley, and I parked the car, there's always 
parking there...So there I am...

Billy: What? Sue, damn! (00:58:08-00:58:28)

She repeats the story one more time and says: "I start to remember...and I... I don't know...I do not know what it is...It's me, Devon, it's me...Nikki..." (00:59:11). Although these two worlds are hard to distinguish, viewers realize that these two levels, hypodiegetic and hypo-hypo diegetic, in Sinnerbrink's words, " mirror and inversely reflect each other, disrupting any boundaries between actor and character, past and future, Cinematic and non-Cinematic worlds" as to create an abysmal world (2011, p.149).

The next nested world, a love drama, takes place in winter in Poland in the 1930s where the story concentrates on The Lost Girl, her family and the Phantom Man. The similar triangle relationship occurs here which apparently is the origin of the gypsy folk tale, the one that Nikki's Polish neighbor foretells at the beginning of the film with "brutal murder",

I can't seem to remember if it's today, two days from now, or yesterday. I suppose if it was 9:45, I'd think it was after midnight! For instance, if today was tomorrow, you wouldn't even remember that you owed on an unpaid bill. Actions do have consequences. (00:16:47-00:17:31)

In a sense, her weird story or vision about murder proved prophetic because in the snow-covered street of Lodz, two murders occurred after midnight, a woman and a man were dead. Besides, the unknown woman in Poland reflects Nikki's image in two ways. First is in sense of identity crisis because she repeats similar demand from two women, "Look at me and tell me if you've known me before" (02:11:24) and receives no satisfactory answer. The second one is in terms of encountering the group of prostitutes. Same prostitutes in Los Angeles appear in Lodz but in the wintry fashions of the 1930s. Concerning this scene, Richard Martin states that "Once again, the Polish scenes in the film act as a ghostly double to the accompanying Hollywood story. 
American actions are placed alongside European doppelgängers, as if the New World is reenacting scenes that have previously occurred in the older continent" $(2011, \mathrm{p} .8)$.

The third mise en abyme world is the scattered Rabbits episode in INLAND EMPIRE. Begun as a web-based series on DavidLynch.com and featuring the voices of Scott Coffey, Laura Harring and Naomi Watts as Jack, Jane and Suzie Rabbits, their non-sequitur one liners "sparking laughter and applause make mysterious incursions into INLAND EMPIRE” (Gleyzon, 2010, p. 86). It seems that Rabbits is a miniaturization of the Sue Blue's world, an intertextual mise en abyme which is embedded in the main course of the story. Rabbits is an "abstract and surreal presentation of the life" of the Nikki/Sue on a microcosmic scale (Devlin \& Biderman, 2001, p. 2).The trio appearance of humanoid rabbits "in a nameless city deluged by a continuous rain" closely mirrors the triangle relationship of Sue, Piotrek and Devon in the primary diegesis. Although rabbit's episode is limited in temporal and spatial term, it presents an image of enough aspects of the whole to be seen as mirroring it (Keen, 2003, p.112).

The apparently non sequitur dialogues of rabbits, in fact, not only act as complementary to the other diegesis levels of film, but also enhance the mise en abyme structure. Take the male rabbit's sentence for example "what time is it?". This sentence is repeatedly uttered by different characters in different diegesis levels. The male rabbit's question "Where was I?" could be taken as a mise en abyme structure because it is the exact sentence of Leonard Shelby in Christopher Nolan's Memento (2000). Suffering from what is called anterograde amnesia, Leonard writes down notes either at the bottom or back of the photos he takes so as to discover his and his wife's murderer's identity. Each photo seemingly functions as an interconnected miniaturization of his world, an abysmal world of entrapment with no way out. Leonard's situation corresponds closely to what Dallenbach quoted from Derrida to illustrate his point in mise en abyme structure; 
"When one can read a book within the book, an origin within the origin, a centre, this leads us into an abyss [abime], a bottomless and infinite duplication"( qtd. in Dallenbach,1989, p. 49).

These narrative levels constitute a mirror, each reflecting the other in interconnected ways; the polish story reflects film within a film, On High Blue Tomorrows. It duplicates Nikki's real life and above all Rabbits' non sequitur lines mirror all these three levels. Lynch use of abysmal worlds in his other films were discussed in previous chapter, so it is unnecessary to deal with them here. Synecdoche, New York (Charlie Kaufman, 2008) and The Thirteenth Floor (Josef Rusnak, 1999) are two notable examples in regard to the concept of infinite duplication of the primary diegesis.

Metafictional writers and filmmakers utilize a variety of strategies to cast doubt on the presented world of either texts or films. Mise en abyme structure of Memento (2000), Synecdoche, New York (2008) and INLAND EMPIRE (2006) are the manifestation of foregrounding technique in postmodern films. These films are embedded with miniature stories of the primary world or diegesis ad infinitum. Another way of distorting the borderline between reality and fiction is the practice of trompe l'oeil, also known as fool the eye.

Similar to Mulholland Drive, INLAND EMPIRE contains some moments that deceive viewers to believe what they are watching is real but after a moment reveals that it is fiction. In Postmodern Fiction, McHale calls this device "trompe l'oeil" (2004, p. 116). It should be noted that non-linearity of film's narrative double the effect because one cannot guess the characters are acting or not. Lynch employs this technique in two scenes.

At the end of the film, Billy's jealous wife, Doris meets the Battered Woman/Sue and stabs her in the stomach and escapes, so do the prostitutes around her. Sue staggered down Hollywood Boulevard and vomits blood on the walk of fame of city of dreams. Unable to stand 
on her feet, Sue lies down between two homeless women, an old African woman and a young Japanese one. Regardless of Sue's appalling situation the two vagabonds engage in a conversation. In between, Sue gets up on all fours and throws up blood on golden star and settles back down to dye. The African woman holds a light in front of her and then she dies. Suddenly a big camera appears and a voice says "Cut... and print it" (02:33:00). It is the director's voice, Kingsley. At this moment, the viewer who takes this very world in the hypodiegetic level, realize that what they are watching is the hypo-hypo-diegetic world. In other words, they have been fooled by Lynch into believing the terrifying and shocking embedded narrative as the primary narrative or storyline. The grotesqueness of death scene is of vital importance because it "intensify ontological instability, titillating or horrifying the reader" and viewer "so as to "resist having to surrender the reality of these materials when they are erased...or dropped down one narrative level" (McHale, 2004, p.116). Gradiva's (Robbe-Grillet, 2006) and Femme Fatale's (Brian De Palma, 2002) erotic and violent scenes produce analogous impact on the viewers.

Lynch uses trompe l'oeil technique in Twin Peaks: Fire Walk With Me as well. When Laura is staring at a picture on her bedroom's wall, the camera zooms into it and suddenly "a nested 'still' representation is transformed before our eyes into an 'animated' sequence" (McHale, 2004, p.118). The narration goes into mysterious Red Room and then comes back. The small portable TV that is given to Dick Laurent provides similar narrative technique in Lost Highway. The picture of the garden in Last Year at Marienbad has the same aim in Alain Resnais' film.

The second moment that Lynch destabilizes the ontological world of his film is in the following scene of Sue's death on street. Hearing the applause of the director and film crew, Nikki stands up in shock and heads out of the film studio unceremoniously. While she is out, unexpectedly she stares directly at the camera and then she appears on a TV screen in the Lost 
Girl's room. A character from the hypodiegetic level is looking at a character in a diegesis level. After shooting the Phantom Man, Nikki opens a door that belongs to Rabbits episode. Actually, through the door, she descends from hypodiegetic level to hypo-hypo-hypodiegetic level. And again via the passage-portal, she reaches the Lost Girl's room at diegetic level. As Sinnerbrink remarks, INLAND EMPIRE's cross boundaries could be interpreted as "psychotopology", a term that he defines as "a topology of cinematic spaces that enfolds disparate but related diegetic worlds, diverging narrative lines, cultural-historical locales, aesthetic sensibilities, and cinematic media" (2011, p. 144). Once they embrace each other, the entire scene is screened on TV as a trompe l'oeil painting. In the end, the film returns back to Nikki's mansion where she and her neighbor were talking about the film she was about to play. "Missing end-frame" is the device applied here. INLAND EMPIRE's narrative, in McHale's words, "drops down to an embedded narrative level without returning to the primary diegesis at the end" (2004, p. 117).

In this section, mise en abyme structure of INLAND EMPIRE was flashed out. The film contains three embedded narratives within itself which are On High Blue Tomorrows, the Polish world and Rabbit's episode. These embedded narratives mirror each other in narrative forms; therefore create a mise en abyme contracture. In addition to mise en abyme device, the trompe l'oeil technique employed in INLAND EMPIRE's narrative was discussed. On the whole the two last films of David Lynch demonstrate abysmal worlds of the main characters' lives as well as the world within world of the film itself. 


\section{BIBLIOGRAPHY}

Bulkeley, Kelly. "Dreaming and the Cinema of David Lynch." Dreaming March 2003: 49-60.

Burningham, Bruce R. "David Lynch and the Dulcineated World." The Cervantes Society of America Fall 2010: 33-56.

Coffeen, Daniel. "This is Cinema:The Pleated Plentitude of th Cinematic Sign in David Lynch's Mulholland Dr." Film-Philosophy March 2003: 1-15.

Dallenbach, Lucien. The Mirror in the Text. Cambridge: Cambridge University Press, 1989.

Devlin, William J. and Shai Biderman. The Philosophy of David Lynch.. Kentucky: The University Press of Kentucky, 2011.

Gleyzon, Francois-Xavier. David Lynch in Theory. Ed. Francois-Xavier Gleyzon. Czech Republic: Littereria Pragensia Books, 2010.

Hill, Val and Peter Every. "Postmodernism and the Cinema." Sim, Stuart. The Routledge Companion to Postmodernism. London \& New York: Routledge, 2001.

Hutcheon, Linda. Narcissistic Narrative: The Metafictional Paradox. Canada: Wilfrid Laurier University Press, 1980.

Jarvie, I.C. Philosophy of the Film: Espistemology, Ontology, Aesthetics. New York: Taylor \& Francis Routledge, 2003.

Keen, Suzanne. Narrative Form. New York: Palgrave, 2003.

Manon, Hugh S. "Seeing Through Seeing Through: The "Trompe l'oeil" Effect and Bodily Difference in the Cinema of Tod Browning." Framework: The Journal of Cinmea and Media Spring 2006: 60-82.

Martin, Richard. "An Old Tale: The Marriage of Lodz and Los Angeles In David Lynch's INLAND EMPIRE." Parallel 25 (2011).

McHale, Brian. Postmodern Fiction. New York: Routledge, 2004. 
McGowan, Todd. The Impossible David Lynch. New York: Columbia University Press, 2007.

McMahon, Laura. "Imitation,Seriality,Cinema:Early Fassbinder and Godard." Peucker, Brigitte. A Companion to Rainer Werner Fassbinder. Chichester, West Sussex: Wiley-Blackwell, 2012.

Olson, Greg. Beautiful Darkness. Toronto: Scarecrow Press, 2008.

Roche, David. "The Death of the Subject in David Lynch's Lost Highway and Mulholland Drive." Poetics of the Subject (2004): 42-52.

Schaffner, Anna Katharina. "Fantasmatic Splittings and Destructive Desires: Lynch's Lost Highway, Mulholland Drive and Inland Empire." Forum for Modern Language Studies (2009): 270-91.

Sheen, E and A Davidson. The Cinema of David Lynch:american dreams, nightmare visions. London and New York: Wallflower Press, 2004.

Sinnerbrink, Robert. "Hollywood In Trouble: David Lynch's INLAND EMPIRE." Sinnerbrink, Robert. New Philosophies of Film: Thinking Images. London \& New York: Continuum, 2011. 141-156.

Thomas, Calvin. "It's No Longer Your Film": Abjection and (the) Mulholland (Death) Drive." Thomas, Calvin. Masculinity, Psychoanalysis, Straight Queer Theory: Essays on Abjection in Literature, Mass Culture, and Film. New York: Palgrave, MacMillan, 2008. 